\title{
The Alteration Tissue Structure of Digestive Diverticulum of Anodonta woodiana Induced by Lead
}

\author{
Renanda Baghaz Dzulhamdhani Surya Putra ${ }^{1}$, Sri Andayani ${ }^{2}$, Hartati Kartika Ningsih², \\ Diana Arfiati ${ }^{2}$, Asus Maizar Suryanto Hertika ${ }^{2 *}$ \\ ${ }^{1}$ Master Program of Fisheries and Marine Sciences, Faculty of Fisheries and Marine Sciences, University of Brawijaya, \\ Malang, Indonesia \\ ${ }^{2}$ Faculty of Fisheries and Marine Sciences, University of Brawijaya, Malang, Indonesia
}

\begin{abstract}
Accumulated the toxic compound such as lead in A. woodiana caused an alteration in the tissue. The aim of the study is observation through histology to determine the alteration of the structure of digestive diverticulum tissue. Anodonta woodiana were maintained in water tub that treated with lead II nitrate exposure $\left(\mathrm{Pb}\left(\mathrm{NO}_{3}\right)_{2}\right)$ 0, 15, 25, 35 mg. $\mathrm{L}^{-1}$ for 7 days to determine the alteration of the damaged structure of the digestive diverticulum and determining water quality such temperature, $\mathrm{DO}$ and $\mathrm{pH}$. The highest damage occurs in digestive diverticulum which treated with $35 \mathrm{mg} . \mathrm{L}^{-1}$ due to many alteration on the tissue structure such as hyperplasia, edema, atrophy, and necrosis with the percentage of total damage about $35 \%$. The lowest alteration tissue structure occurs in $15 \mathrm{mg} . \mathrm{L}^{-1}$ treatment group of the digestive diverticulum. The temperature was observed about $25.3-26.4^{\circ} \mathrm{C}, \mathrm{pH}$ about $6-7$, and DO about 6.1-6.7 mg. $\mathrm{L}^{-1}$. Thus, the increment of lead dose treatment induces increment of tissue structure alteration in digestive diverticula tissue, therefore, might promote the death of $A$. woodiana.
\end{abstract}

Keywords: Anodonta woodiana, digestive diverticulum, histology.

\section{INTRODUCTION}

The common pollutant of heavy metals such as lead $(\mathrm{Pb})$ are considered as toxic pollutants. In addition, the natural aquatic ecology also contaminated with the heavy metals released by domestic activity [1]. The organism or biomass contaminated with the heavy metals may have effect on human health risks $[2,3]$.

As bivalve, the suspension feeding activity of mussel represents the main pathway for heavy metal uptake and accumulation [4,5]. Mussels are suspension feeders both aqueous and dietary; such as material resuspended from sediments. Therefore, it consisted of highmolecular-weight substances, microorganisms, fecal pellets and detritus [6,7]. Mussels are organisms that commonly used to assess the ecotoxicological research in nature to analyze the effects of the compound that released from anthropogenic activities [8,9]. In the previous study, Mussel was used to evaluate In Situ metal contamination in wastewater effluent and in aquatic ecosystems $[10,11]$. The concentration metal in the tissue of mussel was increased concomitantly with the elevating of metal absorption or uptake and it showed the various

\footnotetext{
* Correspondence address:

Asus Maizar Suryanto Hertika

Email : asusmaizar@yahoo.com

Address : Faculty of Fisheries and Marine Sciences, University of Brawijaya, Veteran Malang, Malang 65145.
}

metal bioaccumulation levels in different tissues of mussel $[12,13]$.

Lead is a very toxic heavy metal [14] which cumulative [15] in the gills [16] and gastric [17]. With histopathological analyses, we could observe the alteration of damaged tissue, such as gills and gastric [18] which affected by the contaminants. Lead penetrated the tissues of the body through the respiratory tract [19] and gastrointestinal [20]. It induces the alteration tissue and a functional disorder in $A$. woodiana [21].

Anodonta woodiana (Kijing Taiwan) is a freshwater mussel found in waters with the muddy substrate. Kijing Taiwan lives in bottom waters and is relatively settled. Kijing Taiwan is a filter feeder organism that can filter water and is able to survive in the polluted environment, so it can be used as a bio-indicator of a water body. Lead induces the tissue damage which caused alteration of tissue structure in A. woodiana. The previous study, the histopathology of $A$. woodiana used to monitoring the pollution in aquatic environments and alteration structure of gill and kidney tissue observed [22]. In another study, they observed enlargement of the gastric wall and diverticulum of $A$. woodiana due to exposure to pesticides [23]. The other research on hyperplasia, atrophy, and necrosis occur in the gills of $A$. woodiana due to the Cadmium exposure [24]. However, the tissue structure alteration of digestive diverticulum in $A$. 
woodiana still unknown. The aim of this study was to observed the alteration tissue structure of digestive diverticulum of $A$. woodiana induced by lead II nitrate exposure treatment for 7 days.

\section{MATERIAL AND METHOD Data Collection}

The descriptive qualitative method is used in determining the alteration histology digestive diverticulum of $A$. woodina and water quality in each treatment and data was collected with 3 times experiment repeatition. Anodonta woodiana in size $8-10 \mathrm{~cm}$ obtained from Freshwater Cultivation Management Unit (UPBAT) Punten Batu, Malang and maintained in Workshop Laboratory in Faculty of Fisheries and Marine Science, University of Brawijaya, Malang. Six of $A$. woodiana were induced with Lead Nitrate for 7 days in each treatment and maintained in the circulation system water tub (30 liter volume).

Lead II nitrate $\left[\mathrm{Pb}\left(\mathrm{NO}_{3}\right)_{2}\right]$ dissolved and diluted in the following concentration $0 \mathrm{mg} . \mathrm{L}^{-1}$, $15 \mathrm{mg} \cdot \mathrm{L}^{-1}, 25 \mathrm{mg} \cdot \mathrm{L}^{-1}$, and $35 \mathrm{mg} \cdot \mathrm{L}^{-1}$. Furthermosre, the water quality such as temperature, $\mathrm{pH}$, and $\mathrm{DO}$ in each water tub was measured once in a day for 7 days. After 7 days, the stomach of mussels in each water tub was harvested and immediately, preserved in $\mathrm{dd}_{2} \mathrm{O}$ containing $10 \%$ of formaldehyde. The stomachs were ready for staining and histology analysis.

\section{Histotology analysis}

Histology analysis was conducted according to Elsayed et al. [25]. Briefly, the stomach of $A$. woodiana in each treatment was harvested after treatment and immediately fixed in neutral buffered formaldehyde $10 \%$. Further, the stomachs were dehydrated using ascending grades of ethanol $(70,80,90$, and $100 \%$ for 1 hour in each concentration). The samples were then cleared in xylene. After blocking using soft paraffin, the stomachs were cut using the microtome to serial sections of $4 \mu \mathrm{m}$ thickness. Then, sections were stained using hematoxylineosin stain. After staining, the stomachs were observed with microscope Olympus BX41 and scanned using Olympus CX21FS. The percentage of organ damage is calculated based on the following formula.

Organ damage $(\%)=$ amount of damaged tissue $\times 100 \%$ amount of tissue analyzed

\section{Statistical Analysis}

Data are expressed as mean \pm SD. Statistical significance of pairwise differences among three or more groups was determined using one-way analysis of variance (ANOVA) followed by LSD test. $\quad P<0.05$ was considered statistically significant. The analysis was performed using SPSS for Windows (SPSS Inc., Version 20.0, Chicago, IL, USA). The Graph was performed using GraphPad Prism 7 (GraphPad Software, Inc. USA).

\section{RESULT AND DISCUSSION}

The Morphology of Digestive Diverticulum Tissue Alteration

The alteration of digestive diverticulum tissue of $A$. woodiana in each treatment was shown in Figure 1. The digestive diverticulum induced with $15 \mathrm{mg} . \mathrm{L}^{-1}$ of Lead appeared edema and hyperplasia. The epithelia of digestive diverticulum showed swollen and some cells were grown more (Fig 1B). Further, the atrophy and necrosis of digestive diverticulum were found in A. woodiana which induced with 25 mg. $\mathrm{L}^{-1}$ of Lead (Fig. 1C). The digestive diverticulum was narrowed and its epithelia showed damage. In this treatment, it was revealed that the $A$. woodiana was not resisted to this concentration of Lead. The digestive diverticulum of $A$. woodiana was then found with more necrosis (Fig. 1D). In this treatment group, many alterations of digestive diverticulum was found. It was suggested that above $15 \mathrm{mg} \cdot \mathrm{L}^{-1}$ of Lead, the $A$. woodiana was not resisted the toxicity of Lead. It might cause the death because the digestive diverticulum was damage and was not performed normally. Excretion of mucus is a form of A.woodiana self-protection against the toxic lead. The mucus contained the neutrophils that play a role in digesting foreign substances that penetrate to the body of this organism [24].

Previous study explained that the edema occurs as a form of cell adaptation to survive due to the influence of toxic materials [26]. Enzymes are out of cells along these substances will inhibit cell metabolism. This will ultimately result in cell death (necrosis) [23]. Necrosis is cell death that occurs because of hyperplasia redundant, so tissue no longer intact form or in other words, necrosis occurs accompanied by the death of an organism [27]. 

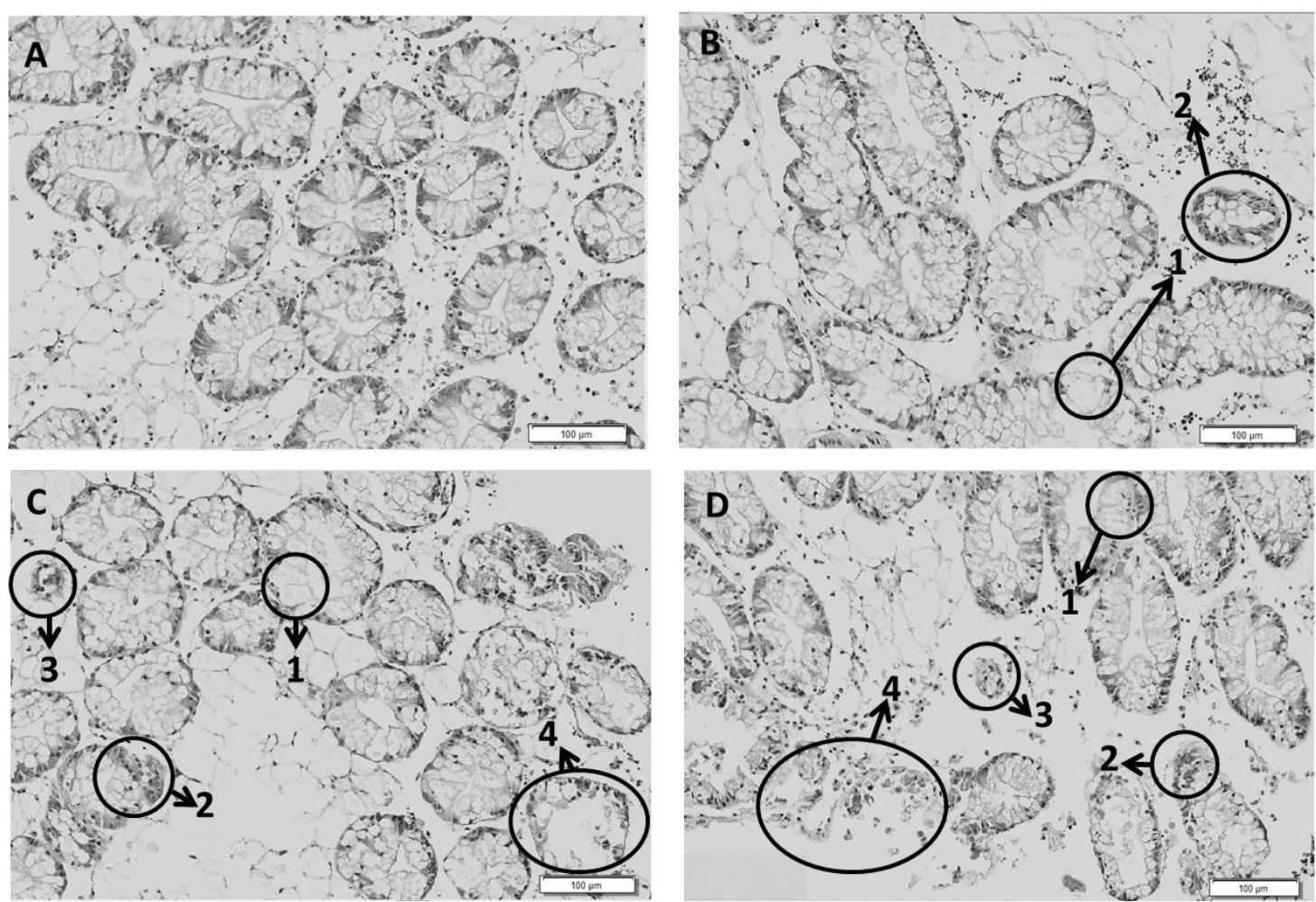

Figure 1. Digestive diverticulum of gastric tissue $A$. woodiana after Lead II Nitrate $\left(\mathrm{Pb}\left(\mathrm{NO}_{3}\right)_{2}\right)$ exposure for 7 days $100 \mu \mathrm{m}$, (magnification 400x, Olympus BX41 microscope, Olympus DP 20 camera). A. treated 0 mg.t-1 lead II nitrate, B. treated $15 \mathrm{mg} . \mathrm{L}^{-1}$ lead II nitrate, C. treated $25 \mathrm{mg} \cdot \mathrm{L}^{-1}$ lead II nitrate, D. treated $30 \mathrm{mg} . \mathrm{L}^{-1}$ lead II nitrate. (1) Edema; (2) Hyperplasia; (3) Atrophy; (4) Necrosis.

\section{The Quantity of Digestive Diverticulum Altera-} tion Analysis

The percentage of alteration on the digestive diverticulum induced by Lead was shown in Figure 2. The hyperplasia was increased significantly in $25 \mathrm{mg} \cdot \mathrm{L}^{-1}$ and $35 \mathrm{mg} \cdot \mathrm{L}^{-1}$ treatment groups about $7.8 \%$ and $9.6 \%$, differently compared to $15 \mathrm{mg} \cdot \mathrm{L}^{-1}$ treatment group about $3 \%$.

Moreover, the necrosis was increased significant in $35 \mathrm{mg} \cdot \mathrm{L}^{-1}$ treatment group around $12 \%$ compare than $25 \mathrm{mg} \cdot \mathrm{L}^{-1}$ treatment group around $3.1 \%$. In the present study, the edema and atrophy were not significant differences in each treatment group. However, the alteration of digestive diverticulum induced $35 \mathrm{mg} . \mathrm{L}^{-1}$ of Lead showed the highest hyperplasia and necrosis was also observed.

The total percentage of digestive diverticulum alteration was shown in Figure 3. The total alteration of digestive diverticulum was increased significantly in $35 \mathrm{mg} . \mathrm{L}^{-1}$ compare to $15 \mathrm{mg} . \mathrm{L}^{-1}$ and $25 \mathrm{mg}^{-\mathrm{L}^{-1}}$ treatment groups. At this moment, the $35 \mathrm{mg}^{-\mathrm{L}^{-1}}$ treatment group has the highest alteration tissue structure of $36 \%$ followed by 25 mg. $\mathrm{L}^{-1}$ for $22 \%$ and $15 \mathrm{mg}^{-\mathrm{L}^{-1}}$ for $8 \%$.
The alteration in gastric tissue begins with edema. The gastric has columnar epithelial cells. The Epithelial cells of the digestive organs column are eosinophilic with an elliptical core. Epithelial cells of the stomach started swelling due to growth. Hyperplasia in epithelial cells is a response of the epithelial cells which are eosinophils [28].

Eosinophils are immune properties of the body against substances that are toxic. On the composition of the cilia starting to look irregular. Thickening of cilia results in fusion of the cilium [29]. In some parts, the gastric walls look thinner. This is caused by cilia and epithelial cells start to shrink (atrophy). Atrophy of the epithelial cells is a form of adaptive reaction to toxic substances that cause digestive activity is not running perfectly so that the needs of the supply of nutrients and hormones is insufficient [30]. Edema and atrophy of the gastric epithelial cells cause the membrane of epithelial cells out of the proponent as well as causing dysfunction organ of the gastric and cause necrosis. Adaptive changes can develop into irreversible characterized by necrosis [31]. 


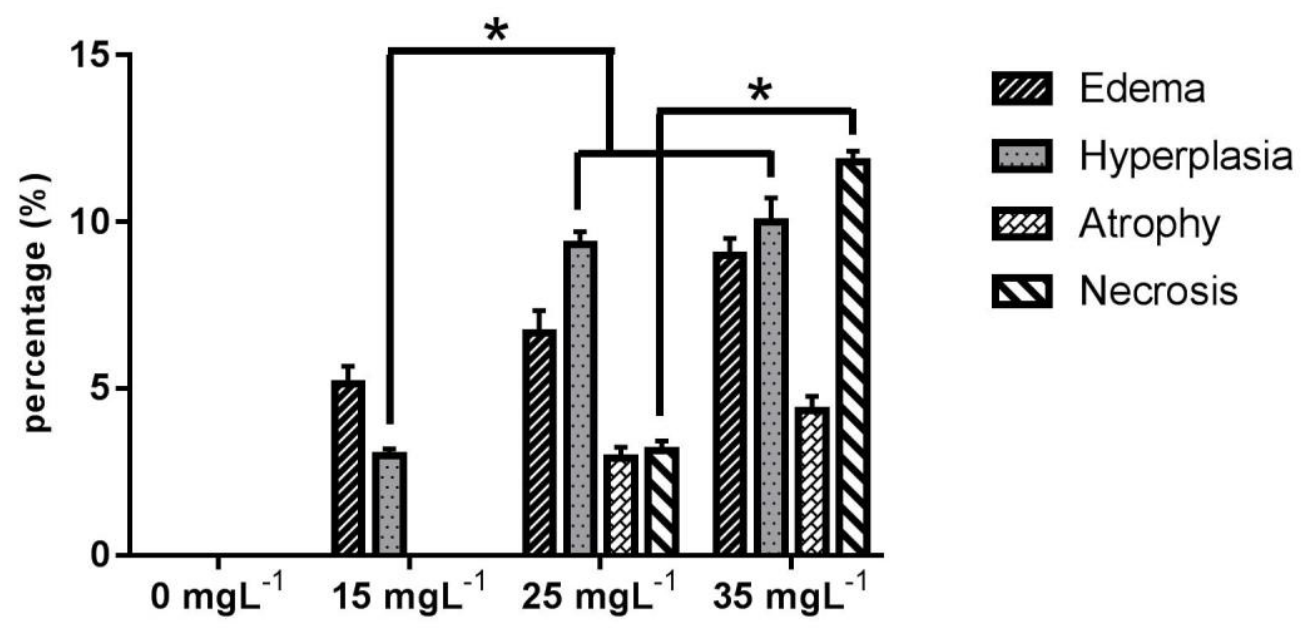

Figure 2. Percentage of each digestive diverticula alteration analysis after Lead II Nitrate $\left(\mathrm{Pb}\left(\mathrm{NO}_{3}\right)_{2}\right)$ exposure for 7 days. Results were the mean \pm SEM; ${ }^{*} p<0.0001$ was significant.

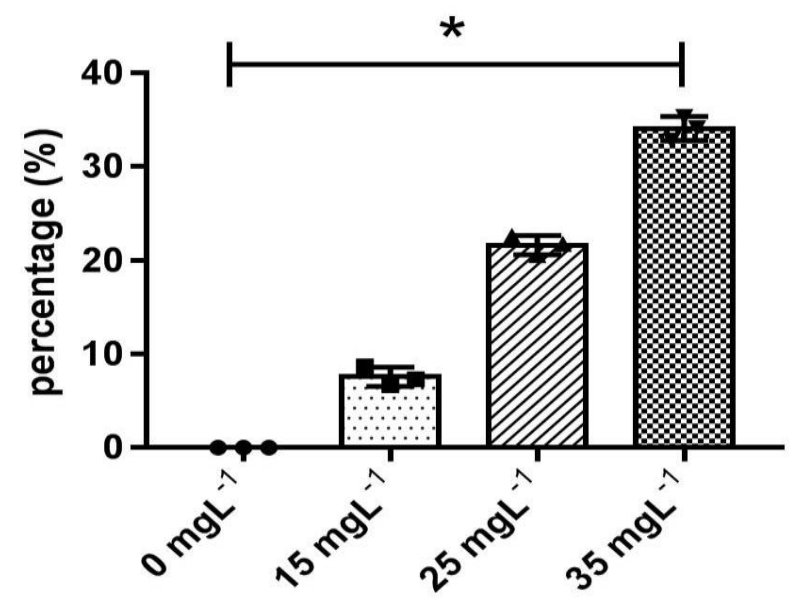

Figure 3. The total percentage of digestive diverticulum alteration of $A$. woodiana after Lead II Nitrate $\left(\mathrm{Pb}\left(\mathrm{NO}_{3}\right)_{2}\right)$ exposure for 7 days Results were the mean \pm SEM; . ${ }^{*} p<0.0001$ was significant.

Digestive diverticulum in bivalves accumulated pollutants, actively participates in the process of detoxification. Digestive diverticulum sensitive targets such as harmful pollutants. In the digestive diverticulum, occur Hyperplasia as indicated by increasing number of cells basophils seen by the assembly dots. Cells in the vesiculated digestive cell showed dominance in the digestive diverticulum. Depreciation cause the digestive diverticulum basophil cells occurred lyses and necrosis in the digestive diverticulum. Alteration in the gastrointestinal cells, basophils cell mass digestion, the out cells and alteration tissue such atrophy and necrosis of the digestive diverticulum, indicating the occurrence of chronic poisoning. This is consistent in previous research of Pillai [32]. Structural cell damage examination indicates that there is enlargement of cells that induce to digestive diverticulum enlarged structure of epithelial cells. cell enlargement resulted in an overall increase in cell volume due to the formation of lysosomes enlarged. then cause gastrointestinal cell atrophy and necrosis. The increment of concentration lead II nitrate treatment induces increment alteration tissue structure in gill tissue and gastric tissue. 


\section{Water Quality Analysis}

The treatment of $\mathrm{Pb}\left(\mathrm{NO}_{3}\right)_{2}$ was not affected the water quality. The present study showed the temperature, $\mathrm{pH}$ and dissolved of oxygen (DO) were inappropriate for the ecological life of $A$. woodiana. A good temperature for the growth of freshwater mussels are temperatures between $15^{\circ} \mathrm{C}-27^{\circ} \mathrm{C}$ [33]. In the observation, $\mathrm{pH}$ and $\mathrm{DO}$ showed it is good for $A$. woodiana life. The $\mathrm{pH}$ is suitable for the environment for $A$. woodiana

\section{A}

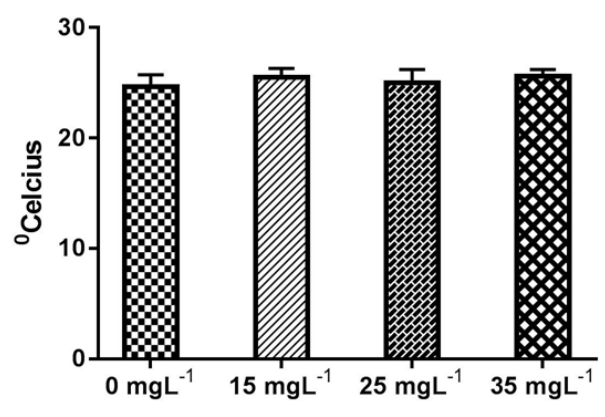

ranging from 6.5 to 7.8 . If the $\mathrm{pH}$ in the water is more or less, the limit could affect the movement of cilia gills [24]. According to Subarijanti, oxygen content which not contained toxic compounds, amounting to a minimum of $2{\mathrm{mg} . \mathrm{L}^{-1}}$ is already sufficient to support the normal life of aquatic organisms [34]. In general, the oxygen obtained taken through gills that produce currents that go into his coat [35].

\section{B}

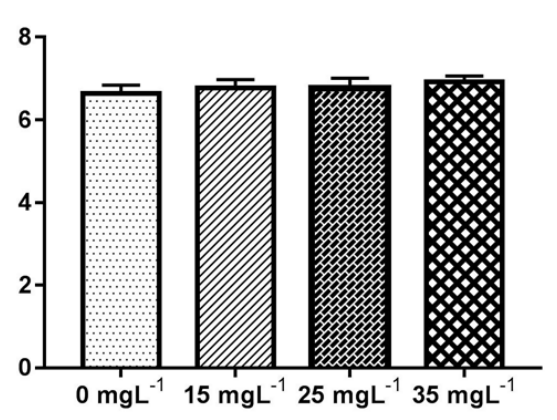

C

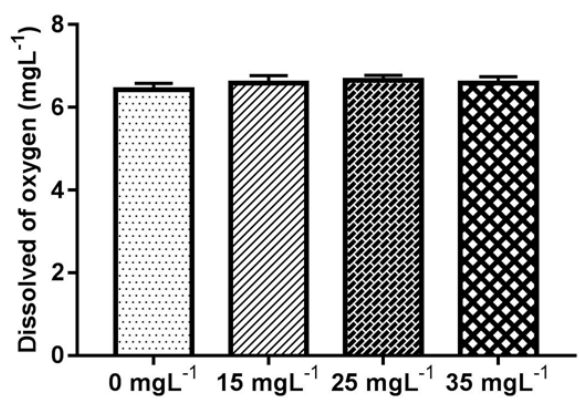

Figure 4. The water quality analysis in Anodonta woodiana tube after Lead II Nitrate $\left(\mathrm{Pb}\left(\mathrm{NO}_{3}\right)_{2}\right)$ exposure for 7 days

\section{CONCLUSION}

These result showed that $A$. woodiana was not resisted with Lead toxicant in the concentration of Lead above $25 \mathrm{mg} \cdot \mathrm{L}^{-1}$. At concentration up to $25 \mathrm{mg} \cdot \mathrm{L}^{-1}$, the $A$. woodiana might death because the digestive diverticulum was not performed normally and it caused by any alteration of digestive diverticulum tissue structure.

\section{REFERENCES}

[1] Velez, D., R. Montoro. 1998. Arsenic speciation in manufactured seafood products: a review. J. food. Protect. 61(9). 1240-1245.

[2] Ja "rup. 2003. Hazards of heavy metal contamination. Brit. Med. Bull. 68. 167-182.

[3] Caussy, D., M. Gochfeld, E. Gurzau, C. Neagu, H. Ruedel. 2003. Lessons from case studies of metals: investigating exposure, bioavailability, and risk. Ecotoxicol. Environ. Safe. 56. 45-51.

[4] Pan, K., W.X. Wang. 2008. Validation of biokinetic model of metals in the scallop Chlamys nobilis in complex field environments. Environ. Sci. Technol. 42. 6285-6290.

[5] Metian, M., M. Warnau, J. L. Teyssie, P. Bustamante. 2011. Characterization of $241 \mathrm{Am}$ and $134 \mathrm{Cs}$ bioaccumulation in the king scallop Pecten maximus: investigation via three exposure pathways. J. Environ. Radioactiv. 102. 543-550.

[6] Galimany, E., M. Ramo'n, M. Delgado. First evidence of fiberglass ingestion by a marine invertebrate (Mytilus galloprovincialis L.) in a N.W. Mediterranean estuary. 2009. Mar. Pollut. Bull. 58. 1334-1338. 
[7] Hull, M.S., P.J. Vikesland, I.R. Schultz. 2013. Uptake and retention of metallic nanoparticles in the Mediterranean mussel (Mytilus galloprovincialis). Aquat. Toxicol. 140-141. 89-97.

[8] Bocchetti, R., C.V. Lamberti, B. Pisanelli, E.M. Razzetti, C. Maggi, B. Catalano, G. Sesta, G. Martuccio, M. Gabellini, F. Regoli. 2008. Seasonal variations of exposure biomarkers, oxidative stress responses and cell damage in the clams, Tapes philippinarum, and mussels, Mytilus galloprovincialis, from Adriatic sea. Mar. Environ. Res. 66. 24-26.

[9] Guidi, P., G. Frenzilli, M. Benedetti, M. Bernardeschi, A. Falleni, D. Fattorini, F. Regoli, Scarcelli, M. Nigro. 2010. Antioxidant, genotoxic and lysosomal biomarkers in the freshwater bivalve (Unio pictorum) transplanted in a metal polluted river basin. Aquat. Toxicol. 100. 75-83.

[10] Gagnon, C., F. Gagné, P. Turcotte, I. Saulnier, C. Blaise, M.H. Salazar, S.M. Salazar. 2006. Exposure of caged mussels to metals in a primary-treated municipal wastewater plume. Chemosphere. 62. 9981010.

[11] Gillis, P.L., F. Gagné, R. McInnis, T.M. Hooey, E.S. Choy, C. André, M.E. Hoque, C.D. Metcalfe. 2014. The impact of municipal wastewater effluent on field-deployed freshwater mussels in the Grand River (Ontario, Canada). Environ. Toxicol. Chem. 33(1). 134-143.

[12] Yeager-Armstead, M., J.L. Yeager. 2007. In Situ toxicity testing of unionids. In: Farris, J.L., J.H. Van Hassel (Eds). Freshwater Bivalve Ecotoxicology. Boca Raton (FL). CRC Press. 135-149.

[13] Jebali, J., L. Chouba, B. Mohamed, H. Bousetta. 2014. Comparative study of the bioaccumulation and elimination of trace metals ( $c d, P b, \mathrm{Zn}, \mathrm{Mn}$ and $\mathrm{Fe}$ ) in the digestive gland, gills and muscle of bivalve Pinna nobilis during a field transplant experiment. J. Trace Elem. Med. Biol. 28(2). 212-217.

[14] Supriyanto, C., Samin, Z. Kamal. 2007. Analyses of heavy metals contamination $\mathrm{Pb}$, $\mathrm{Cu}$, and $\mathrm{Cd}$ on freshwater fish Degan method Nyala atomic absorption spectrophotometry (AAS). Proceedings of the Third National Seminar on Human Resources for Nuclear Technology. Yogyakarta. 147-152.
[15] dan Gul, Y. 2003. Histopathological effects of cadmium and copper on the sea scallop Placopecten magellanicus. Marine Pollution and Physiology: Recent Advances. University of South Carolina Press. Columbia, SC. 187-198.

[16] Sunarto. 2007. Bioindikator pencemar logam berat Cadmium ( $\mathrm{Cd}$ ) dengan analisis struktur mikroanatomi, efisiensi fungsi insang, morfologi dan kondisi cangkang kerang air tawar (Anodonta Woodiana Lea). PhD Thesis. Airlangga University. Surabaya.

[17] Gopinathan, K. M., R. S. Amma. 2006. Bioaccumulation of toxic heavy metals in the edible soft tissues of green mussel (Perna viridis L.) of Mahe region. Project report submitted to the Department of Science, Technology and Environment (DSTE), Government of Pondicherry. India.

[18] Setyowati, A., D. Hidayati., P.D.N. Awik., N. Abdulgani. 2007. Studi histopatologi hati Ikan Belanak (Mugil cephalus) di Muara Sungai Aloo Sidoarjo. Research Report. Department of Biology. Sepuluh Nopember Institute of Technology. Surabaya.

[19] Erlania, A.I., Gubawan, Y.H. Prihadi. 2007. Cultivation potential Kijing Taiwan (Anodonta woodiana) In Cirata. Proceedings of the National Seminar Mollusks in Research, Conservation and Economic. Aquaculture Research Center. Jakarta.

[20] Galtsoff, P.S. 1964. The American oyster (Crassostrea virginica). Fishery Bulletin of The Fish and Wildlife Service. 489.

[21] Soegianto, A., N.A. Primarastri, D. Winarni. 2004. Pengaruh pemberian kadmium terhadap tingkat kelangsungan hidup dan kerusakan struktur insang dan hepatopankreas pada udang Regang [Macrobrachium Sintangense (De Man). Berk. Penel. Hayati. 10. 59-66.

[22] Widiastuti. 1997. Kijing Air Tawar sebagai alat pemantau pencemaran perairan logam berat. Bachelor Thesis. Department of Biology, Bogor Agricultural University. Bogor.

[23] Lesmana, G.L., D. Arfiati, A. Maizar, 2013. Pengamatan jaringan lambung Kijing Taiwan (Anodonta woodiana Lea) yang terdedah pestisida Diazinon 60 EC pada beberapa konsnetrasi. J. Exp. Life Sci. 3(1). 37-39.

[24] Fitriawan, F. 2010. Analyses of change and variation pattern ribbon mikroanatomi isozyme at gills and kidneys freshwater mussels Anodonta woodiana against heavy 
metal Cadmium exposure. Thesis. Sebelas Maret university. Surakarta.

[25] Elsayed, E.E., N.E. El Dien, M.A. Mahmoud. 2006. Ichthyophthiriasis: various fish susceptibility or presence of more than one strain of the parasite?. Nat. Sci. 4(3). 5-13.

[26] Widayati, D.E., Aunurohim, A. Nurlita. 2011. Histopatologi mempelajari Insang Ikan Mujair (Oreochromis mossambicus) pada konsentrasi subletal Air Lumpur Sidoarjo. Sepuluh Nopember Institute of Technology. Surabaya.

[27] Laksman, H. T. 2003. Medical Dictionary. Djambatan. Jakarta.

[28] Andrew, M., Stephen A.B. 2014. Histological atlas of freshwater mussels (Bivalvia, Unionidae): Villosa nebulosa (Ambleminae: Lampsilini), Fusconaia cerina (Ambleminae: Pleurobemini) and Strophitus connasaugaensis (Unioninae: Anodintini). Malacologica. 57(1). 99-239

[29] Hoey, D. A., M.E. Downs, C.R. Jacobs. 2012. The mechanics of the primary cilium: an intricate structure with complex function. J. Biomech. 45(1). 17-26.

[30] Sarjadi. 1999. Pathology and systematic. EGC Medical Book Publisher. Jakarta.

[31] Raza'i, T.S. 2008. Analisis histopatologi organ insang dan usus ikan Kerapu Lumpur (Epinephelus coioides) yang diberi Khamir Laut (Marine 5 Yeast) sebagai imunostimulan. Master Thesis. Faculty of Fisheries and Marine Sciences, University of Brawijaya. Malang.

[32] Pillai, S.P. 1993. Heavy metal toxicity in bivalve histological and histochemical enquiry. Thesis. Cochin University. India.

[33] Rachman, B., D. Hasbullah, Rahmat. 2006. Application of poly between shellfish (Hyriopsis Sp.) with the Tilapia and Mola in production efforts prospective parent and freshwater pearls. Engineering Annual Report. Freshwater Aquaculture Centres. Sukabumi.

[34] Subarijanti, H. 1990. Limnology. of Fisheries and Marine Sciences, University of Brawijaya. Malang.

[35] Nontji. 2002. Preservation and management of water resources in tropical coastal areas. PT. Gramedia Pustaka. Jakarta. 